\title{
Cover crops as a weed seed bank management tool: A soil down review
}

\author{
Cynthia Sias, ${ }^{1}$ Bethany R. Wolters, ${ }^{2}$ Mark S. Reiter, ${ }^{3}$ Michael L. Flessner ${ }^{1}$ \\ ${ }^{1}$ School of Plant and Environmental Sciences, Virginia Tech, Blacksburg, VA; ${ }^{2}$ Department of Agriculture, \\ Geosciences and Natural Resources, University of Tennessee at Martin, Martin, TN; ${ }^{3}$ Eastern Shore \\ Agricultural Research and Extension Center, Virginia Tech, Painter, VA, USA
}

\begin{abstract}
Highlights
- Cover crops alter the weed seed bank environment, influencing survival, dormancy, and germination.

- Weed seed germination may be reduced by decreased temperature and fluctuations thereof, light, and soil nitrogen.

- Weed seed germination may be increased by greater soil moisture, soil nitrogen, and oxygen.

- Management should maximize cover crop biomass, decrease soil nitrogen, and delay termination for the greatest potential.

- Future research should include measurements of weed seed banks, including dormancy status, predation, and germination.
\end{abstract}

\begin{abstract}
This review explores ways that cover crops alter soil environmental conditions that can be used to decrease seed survival, maintain weed seed dormancy, and reduce germination cues, thus reducing above-ground weed pressures. Cover crops are grown between cash crops in rotation, and their residues persist into subsequent crops, impacting weed seeds both during and after cover crops' growth. Compared to no cover crop, cover crops may reduce weed seedling recruitment and density via: i) reducing soil temperature and fluctuations thereof; ii) reducing light availability and altering light quality; and iii) trapping nitrogen in the cover crop, thus making it less soil-available to weeds. In addition, cover crops may provide habitat for above- and below-ground fauna, resulting in increased weed seed predation. The allelopathic nature of some cover crops can also suppress weeds. However, not all effects of cover crops discourage weeds, such as potentially increasing soil oxygen.
\end{abstract}

Furthermore, cover crops can reduce soil moisture while

Correspondence: Michael L. Flessner, School of Plant and Environmental Sciences, Virginia Tech, Blacksburg, VA, USA.

E-mail: flessner@vt.edu

Key words: Soil seed bank; integrated weed management; sustainability; germination; seed dormancy.

Received for publication: 24 February 2021.

Revision received: 21 September 2021.

Accepted for publication: 21 September 2021.

(C) Copyright: the Author(s), 2021

Licensee PAGEPress, Italy

Italian Journal of Agronomy 2021; 16:1852

doi:10.4081/ija.2021.1852

This article is distributed under the terms of the Creative Commons Attribution Noncommercial License (by-nc 4.0) which permits any noncommercial use, distribution, and reproduction in any medium, provided the original author(s) and source are credited. actively growing but conserve soil moisture after termination, resulting in time-dependent effects. Similarly, decaying legume cover crops can release nitrogen into the soil, potentially aiding weeds. The multiplicity of cover crop species and mixtures, differing responses between weed species, environmental conditions, and other factors hampers uniform recommendations and complicates management for producers. But, cover crops that are managed to maximize biomass, do not increase soil nitrogen, and are terminated at or after cash crop planting will have the greatest potential to attenuate the weed seed bank. There are still many questions to be answered, such as if targeting management efforts at the weed seed bank level is agronomically worthwhile. Future research on cover crops and weed management should include measurements of soil seed banks, including dormancy status, predation levels, and germination.

\section{Introduction}

The growing struggles of herbicide-resistant weeds and regulations have led weed scientists to search for other means of weed suppression and management (Powles and Gains, 2018). Critical research into cover crops has established them as a successful yet multi-dimensional option for weed management (Mirsky et al., 2013; Osipitan et al., 2018). Cover crops are also well documented to alter soil environmental conditions such as temperature, moisture, light, oxygen, and nitrogen availability, among the most critical influencers of seed dormancy and germination (Figure 1) (Hilhorst and Toorop, 1997; Benech-Arnold et al., 2000). Beyond these factors, cover crops can provide habitat for microbes, pathogens, and above- and below-ground fauna as well as allelopathic effects, all of which play a role in weed seed fate (Figure 2 ). The ability to manipulate the weed seed bank environment through cover crops in order to reduce weed seed survival, promote dormancy, or discourage germination is a tool that can potentially be used as an integrated weed management tactic (Dyer, 1995; Gallandt, 2006; Teasdale, 1996; Mirsky et al., 2010; Haring and Flessner, 2018). However, current review papers do not explicitly link weed seed fate to cover crops.

Following is a review of literature that has contributed to our understanding of the effect of these different environmental fac- 
tors on weed seed fate. Our objective is to connect literature on weed seed fate to literature on how cover crops alter the environment surrounding weed seeds. We stop short of weed establishment as this is covered in other works (Osipitan et al., 2018). While much of this review applies to many cover crop systems, we focus on cover crops planted in the fall and terminated in the spring before planting a summer cash crop, common in cropping systems in many parts of the world (Stewart et al., 2018; Jian et al., 2020). Understanding cover crops' impact on weed seeds will help direct future research and serve as a starting point for those seeking to utilize cover crops and/or provide recommendations to producers.

\section{The interplay of cover crops and seed dormancy and germination}

\section{Light}

Light conveys important information regarding burial depth and the presence or absence of a plant canopy to seeds. For this reason, light is required to break seed dormancy and promote or inhibit germination in some species (Batlla and Benech-Arnold, 2014). Since light must pass through the cover crop before reaching weed seeds on or in the soil, cover crops may be able to reduce weed seedling density. The question is simply if cover crops can alter light sufficiently to maintain dormancy or stop germination.

An actively growing cover crop will reduce both overall light quantity and the red to far-red ratio, which indicates a plant canopy and can reduce germination (Batlla and Benech-Arnold, 2014). Certain cover crops block more light than others. For example, hairy vetch (Vicia villosa) can reduce light penetration by $>99 \%$ (Teasdale and Daughtry, 1993). Hairy vetch and hairy vetch/barley (Hordeum vulgare) reduced photosynthetically active light penetration to $\leq 47 \mu \mathrm{mol} \mathrm{m}^{-2} \mathrm{~s}^{-1}$, whereas light at the soil level under a barley canopy was reduced to $143 \mu \mathrm{mol} \mathrm{m}^{-2} \mathrm{~s}^{-1}$ (Wayman et al.,
2015). Terminated cover crop residues do not affect the light quality (red to far-red ratio) (Teasdale and Mohler, 1993) and are less effective at reducing light quantity compared to living cover crops (Teasdale and Daughtry, 1993; Wayman et al., 2015). However, terminated cover crop residues can block up to $80 \%$ of the total light transmission to the soil surface when present at $\geq 6000 \mathrm{~kg} \mathrm{ha}^{-1}$ (Teasdale and Mohler, 1993). Therefore, more residue results in a more significant reduction in light penetration; up to $85 \%$ reduction in photosynthetically active radiation resulted from cereal rye (Secale cereale) or wheat residues at 10,000 kg ha-1 but $4000 \mathrm{~kg}$ $\mathrm{ha}^{-1}$ only resulted in a $60 \%$ reduction (Rector, 2019).

To completely maintain dormancy, full sunlight needs to be reduced to $<0.1 \%$ (Smith, 1986); neither actively growing nor terminated cover crops reach this level (Teasdale and Mohler, 1993). Germinated weeds need at least 20 to $50 \mu \mathrm{mol} \mathrm{s}^{-1} \mathrm{~m}^{-2}$ or about $1 \%$ of full sunlight to survive (Smith, 1986). Most terminated cover crop residues do not reduce light sufficiently to inhibit germination, but dense, actively growing cover crop canopies may reach this level (Teasdale and Daughtry, 1993). Indeed, germination of Ambrosia artemisiifolia and multiple Amaranthus species are adversely affected by reduced light (Pickett and Baskin 1973; Gallagher and Cardina, 1998; Jha et al., 2010).

While reducing the light in a sufficient way to maintain complete dormancy is not possible, partial dormancy can be realized with cover crops. Batlla and Bench-Arnold (2014) conclude that regulation of weed emergence by the presence of a crop canopy will depend on the overlap between the 'emergence window' of the weed and the density of the crop canopy that is modifying the environmental signals that affect seed germination. Even small changes in light, such as those from a developing crop canopy, can suppress the germination of some weeds. Therefore so-called 'planting green' (planting the cash crop while the cover crop is still living) is likely to be the most successful in using cover crops to affect light and thus weed seedling density (Teasdale and Daughtry, 1993).

For a producer to further capitalize on this effect, other consid-

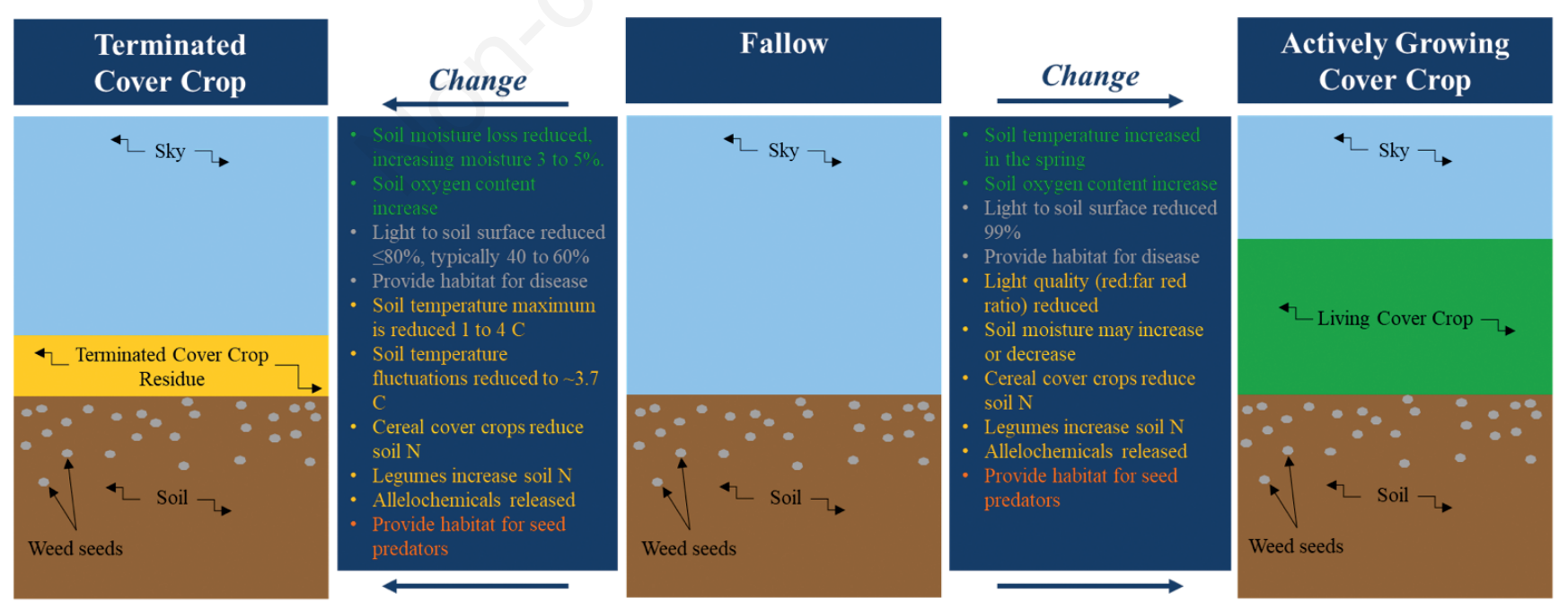

Figure 1. Changes in the environment surrounding weed seeds as a result of actively growing cover crops, living cover crop (left) and terminated, dead cover crop residue (right) compared to fallow (centre). The deeper the seeds position in the soil, the less pronounced the change. The colour of the text indicates the dormancy or germination response of weed seeds. Red text indicates inhibition, the yellow text indicates variable response, the green text indicates promotion of weed germination, and the grey text indicates neither a neutral response (neither inhibition nor promotion). 
erations need to be considered. Firstly, not all weed species are light-sensitive as seeds. For example, Bromus catharticus and Avena fatua will germinate in darkness (Alshallash, 2018). In general, small-seeded weeds are more sensitive to light than largeseeded weeds since they have few endogenous resources to emerge from the depth and reach light or compete with other plants for it (Forbis et al., 2002; Batlla and Bench-Arnold 2014).

Additionally, the termination method impacts light intensity (Teasdale and Mohler, 1993; Wayman et al., 2015; Rector, 2019). Cover crop mulches that are flail mowed transmit more light than other termination methods that leave residues intact (Teasdale and Mohler, 1993), and rolled cover crop residue blocks about 5\% more light than standing residue (Rector, 2019). As cover crop residue decays, a greater light quantity will transmit through the residue following an exponential decay trend (Teadale and Mohler, 1993). Legume cover crops typically degrade faster than grasses, potentially making cover crop species a critical consideration (Sievers and Cook, 2018). Therefore, selecting cover crops that persist after termination and using termination methods that leave residues intact are best practices for producers in this regard.

\section{Soil temperature}

Seeds that germinate in an unfavourable season or exhaust energy reserves before reaching sunlight by emerging from too great a depth will perish. Soil temperature and fluctuations thereof are significant drivers of dormancy and germination because they convey information about season and depth of burial to the seed (Benech-Arnold et al., 2000; Batlla and Benech-Arnold, 2014). Cover crops reduce temperature fluctuations and lower maximums in soil temperature. Thus, cover crops have the potential to keep the weed seed bank in a dormant state, at least in part, or delay emergence.

Cereal rye and hairy vetch cover crop residue left on the soil surface reduced maximum soil surface temperature but had little effect on minimum soil temperature over the winter months (Teasdale and Mohler, 1993; Teasdale, 1996). However, soil tem- perature effects will be minimized if the cover crop is removed or incorporated into the soil. Teasdale and Mohler (1993) found that surface residues lowered maximum soil temperature at $5 \mathrm{~cm}$ by 2.7 to $3.3^{\circ} \mathrm{C}$. Kahimba et al. (2008) found that soil under a cover crop had warmer temperatures in the frozen soil layer than winter fallow. Teasdale and Mohler (1993) found that during the summer months, cereal rye and hairy vetch cover crop mulches lowered soil temperatures 1 to $4^{\circ} \mathrm{C}$ compared to the bare soil control at 2 to $5 \mathrm{~cm}$ depth. However, the temperature reduction was more significant, and lasted longer under the cereal rye than the hairy vetch due to lesser biomass and faster decomposition of the hairy vetch.

Seeds of summer annual weed species break dormancy in response to cold soil temperatures over the winter, increasing soil temperatures during the spring, and vice versa for seeds of winter annuals (Benech-Arnold et al., 2000). For example, the germination of the summer annual weed Abutilon theophrasti increased when exposed to $36^{\circ} \mathrm{C}$ after $4^{\circ} \mathrm{C}$ (Leon and Owen, 2003). Thus, reducing maximum soil temperature may lead to delayed seed germination or help to maintain dormancy. For example, some weed seeds, such as those in the Solanaceae and Apiaceae, only germinate when temperatures exceed $20^{\circ} \mathrm{C}$ (Geneve, 2003).

In addition to soil temperature, fluctuations in soil surface temperature are attenuated in the presence of a cover crop or its residue. For example, Teasdale and Mohler (1993) found that soil temperature variations were reduced between 3.6 to $3.8^{\circ} \mathrm{C}$, compared to bare soil in the month after termination, but this amount was not enough to prevent the germination of weeds. Nonetheless, there may be a value from reducing soil temperature fluctuations, as Teasdale and Mohler (1993) speculated that weed emergence might be delayed as a result.

Additionally, fluctuations in soil temperature may also lead to seed germination. Geneve (2003) found that some seeds require temperature fluctuations $>15^{\circ} \mathrm{C}$ in order to germinate. Nevertheless, some species are sensitive to temperature fluctuations of $<5^{\circ} \mathrm{C}$, including Chenopodium rubrum and Rumex crispus (Thompson and Grime, 1983). Thompson and Grime (1983) found

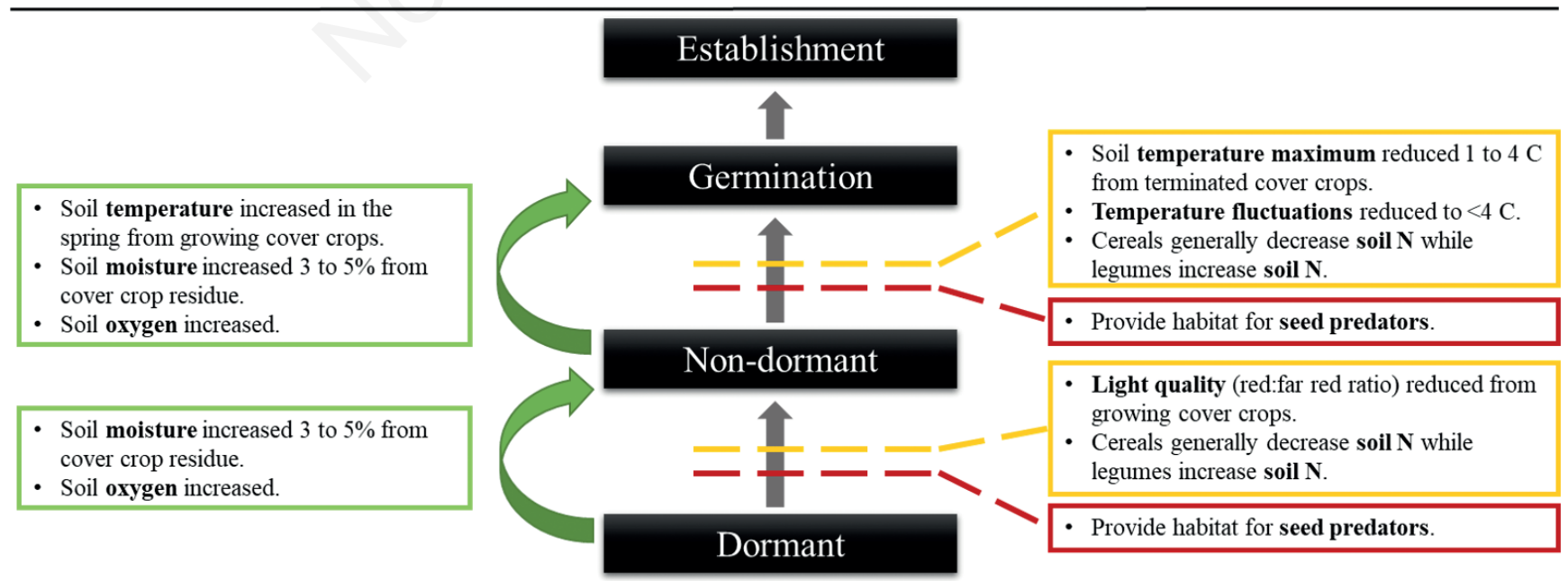

Figure 2. Potential for cover crops to promote (green), reduce in some but not all cases (yellow), or inhibit (red) advancements in weed seed state toward the establishment. Figure adapted from Rius and Darling (2014). 
that germination was stimulated by temperature fluctuations in $18 \%$ of 61 species common to disturbed ground regardless of the presence or absence of light, indicating that exposure to temperature fluctuations is the main germination trigger for some weed species.

Reduced fluctuations and lowered maximums in soil temperature under cover crops could inhibit seed germination, at least in part, or delay emergence. This could potentially give the cash crop a competitive advantage when establishing ahead of the weedy species. To capitalize on this effect, producers should maximize cover crop biomass production and use termination and planting methods to maintain residue cover through as much of the growing season as possible.

\section{Soil moisture}

Like soil temperature, fluctuations in soil moisture may communicate soil depth to weed seeds as the most significant fluctuations are near the soil surface (Batlla et al. 2007). Increased soil moisture fluctuations can decrease weed seed dormancy (Batlla and Benech-Arnold, 2014), but germination will not occur without adequate moisture (Hilhorst and Toorop, 1997). Thus, cover crops can both increase and decrease soil moisture through various means, creating a potential management opportunity to promote dormancy and reduce germination.

Cover crops can increase soil moisture by decreasing water runoff, decreasing evaporation, and increasing infiltration during both active growths and via their mulch after termination. For example, Zhu et al. (1989) found that water runoff could decrease between $30 \%$ to $36 \%$ when the ground was covered with a winter cover crop compared to the no-cover checks. In addition, Joyce et al. (2002) reported greater soil water storage capacity in a cover crop compared to conventional till winter fallow. Conversely, cover crops take up soil moisture during active growth, resulting in drier conditions if cover crop termination is delayed in moisture limiting conditions (Liebl et al., 1992; Clarke et al., 1997; Joyce et al., 2002). Conversely, producers can use the cover crop to reduce soil moisture when there is a moisture surplus.

After termination, intact cover crop residues can act as a mulch layer reducing soil moisture loss compared to no cover crop, which may increase weed seedling recruitment and seedling density. Increased soil moisture under cover crop biomass mulch is the only factor increasing weed germination in a framework used by Mirsky et al. (2013) to describe the use of a cereal rye cover crop for weed control. In soybean, cover crop residue presence increased soil moisture by $3 \%$ to $5 \%$ compared to the no-cover check at 0 to $30 \mathrm{~cm}$ soil depth (Acharya et al., 2019). A similar range was reported by Teasdale and Daughtry (1993). The soil moisture content increases with cover crop biomass production (Teasdale and Mohler, 1993; Clarke et al., 1997; Rector, 2019). Like cover crop mulch effects on light penetration, effects on soil moisture are reduced as the mulch decomposes (Teasdale and Mohler, 1993), potentially making cover crop species choice important due to varying degradation rates.

Varying effects of cover crops on soil moisture, the inability to control or adequately predict rainfall, and the unpredictable performance of cover crops (i.e., biomass accumulation) make this aspect of using cover crops to target the weed seed bank problematic. Furthermore, while termination timing can be used to manage soil moisture, these decisions are often dictated by the crop and equipment concerns rather than weeds.

\section{Oxygen content}

In concert with temperature, moisture, and light, oxygen concentration may also communicate burial depth to seeds. Anoxia, the lack of oxygen, can prevent seed germination and keep seeds dormant (Benvenuti and Macchia, 1995; Benech-Arnold et al., 2000). To our knowledge, the literature does not directly relate soil oxygen to cover crops, but cover crops can increase soil porosity, aggregate stability, and water holding capacity as well as decrease bulk density and penetration resistance compared to bare soil (Villamil et al., 2006). In addition, soil physical properties and aggregate formation are related to soil qualities such as water holding capacity and compaction, all of which influence soil oxygen content (Horn et al., 1994; Blanco-Canqui et al., 2011). Therefore, cover crops may also influence weed seed fate via impacts on soil oxygen.

Deep tap-rooted cover crops like rapeseed (Brassica napus) and tillage radishes (Raphanus sativus) are frequently used to relieve subsurface compaction (Chen and Weil, 2010). Tillage radishes leave noticeably large holes in the soil that increase infiltration (Weil and Kremen, 2007) and likely aeration. Cereal rye, which has a fibrous root system, can also increase soil porosity and aeration as much as radish and rapeseed, compared to no cover crop control, but only in soils with low compaction (Chen et al., 2014). It is also understood that larger aggregates and greater soil porosity that these root systems can create increase oxygen diffusion rates (Lemon and Erickson, 1952).

Boyd and Van Acker (2004) report that Echinochloa crus-galli germination was reduced when exposed to ambient oxygen levels at the soil surface. Conversely, wild mustard germination increased with increasing oxygen concentration. However, other species germination, such as Setaria viridis, are generally not influenced by oxygen. For some weeds, moisture and light are more important factors for germination than oxygen (Benech-Arnold et al., 1998; Boyd and Van Acker, 2004).

To the extent that cover crops increase soil aeration, previously anaerobic soil microsites that contain seeds could become aerobic, possibly stimulating germination. Thus, increased soil porosity and aeration may increase soil micro and macrofauna activity, which can affect weed seed predation and impact the weed seed bank. Conversely, cover crops also have the potential to increase root biomass and root respiration due to greater porosity and increased moisture availability, which would decrease soil oxygen. Therefore, this relationship is unclear and should be the subject of more research.

\section{Nitrogen availability}

Plant available soil nitrogen $(\mathrm{N})$ level can stimulate weed germination because it signals less plant competition for resources (Dyer, 1995). Cover crops can increase and decrease plant available N, potentially allowing producers to use cover crops to manage weeds via their effects on plant available $\mathrm{N}$.

Cover crops can decrease plant available $\mathrm{N}$ in two ways. First, while growing, grass and brassica cover crops will reduce soil $\mathrm{N}$ concentrations by scavenging nutrients from the soil. Once terminated, grass cover crops and mixtures with high $\mathrm{C}: \mathrm{N}$ ratios will decrease soil $\mathrm{N}$ availability at least temporarily. Brassicas, for example, decrease soil $\mathrm{N}$ in the fall after being planted and then release it back in the spring (Weil and Kremen, 2007).

Certain cover crop species such as cereal rye, are more apt for $\mathrm{N}$ scavenging due to their root structures, and therefore reduce $\mathrm{N}$ leaching to a greater extent relative to other cover crop species (Sainju et al., 1998). Low soil N may decrease weed seed germi- 
nation in early spring if cover crops are scavenging and depleting soil $\mathrm{N}$ over the winter. Kaye et al. (2019) found that across six cover crop monocultures and four cover crop mixtures, all cover crop plots were more successful at reducing $\mathrm{N}$ leaching by up to $90 \%$ compared to fallow plots during their growth.

Legume cover crops can increase soil $\mathrm{N}$ via $\mathrm{N}$ fixation during active growth and via decomposition after termination. Plant available soil $\mathrm{N}$ will increase as cover crops decompose, especially legumes, which could stimulate germination just as the cash crop is being planted. Cook et al. (2010) found that hairy vetch that was terminated in late May produced higher amounts of biomass and therefore higher amounts of plant available $\mathrm{N}\left(\sim 50 \mathrm{~g} \mathrm{~kg}^{-1} \mathrm{~N}\right)$ compared to treatments terminated earlier in May. This same study concluded that although the biomass accumulation of hairy vetch was very climate-dependent, the total biomass accumulation increased due to delayed termination. Therefore, cover crop termination timing is an important management decision for weed suppression when considering the effect of legume biomass accumulation and resulting effects on plant available N. Mohler et al. (2018) evaluated the seed fate of two N-sensitive weeds (Chenopodium album and Amaranthus powellii) and two primarily $\mathrm{N}$-insensitive weeds (Setaria faberi and Abutilon theophrasti) and found that hairy vetch reduced the persistence of the N-sensitive weeds by causing fatal germination, but had no effect on persistence of the other weeds.

Weed seed responses to plant available $\mathrm{N}$ are variable. Fawcett and Slife (1978) evaluated weed seeds fertilized with up to $448 \mathrm{~kg}$ $\mathrm{N} \mathrm{ha}^{-1}$ but observed no increase in germination. Similarly, germination of Amaranthus retroflexus and Setaria glauca did not respond to soil ammonium or nitrate additions (Schimpf and Palmblad, 1980). Conversely, Avena fatua germination increased in response to nitrate fertilizer (Sexsmith and Pittman, 1963).

Similarly, germination of Ambrosia trifida and Eriochloa villosa responded to soil N. Varying responses across species may occur because $\mathrm{N}$ sensitivity is linked with other environmental factors such as light (Dyer, 1995). Plant available N can also increase growth after germination, but if seeds are truly dormant, they will not imbibe exogenous N (Fawcett and Slife, 1978). Lastly, N itself is not always enough to influence dormancy or promote germination (Derkx and Karssen, 1994).

$\mathrm{N}$ availability for mother plants during seed development can influence dormancy, but there is no consistent response among species (Baskin and Baskin, 1998; Hilhorst, 2007). For example, Chenopodium album seeds produced in high N conditions contained more significant amounts of nitrate and germinated faster than seeds grown with no supplemental N (Fawcett and Slife, 1978). In contrast, Abutilon theophrasti seeds did not have elevated nitrate contents or high germination rates in the field. Thus, inter-seeded or early-planted cover crops may reduce plant available $\mathrm{N}$ during weed seed development and promote dormancy, which may be an effective management strategy to decrease germination of $\mathrm{N}$-sensitive species. More research is needed in this regard.

Reducing plant available $\mathrm{N}$ before a legume cash crop is an effective strategy for $\mathrm{N}$-sensitive weed species. However, producers should select cover crop species that scavenge $\mathrm{N}$ and have a high $\mathrm{C}: \mathrm{N}$ ratio at termination for best results. Reducing soil- $\mathrm{N}$ is not an option in crops with high $\mathrm{N}$ requirements, such as maize or cotton. More research is needed to examine $\mathrm{N}$ release from decomposing cover crops and interactions with weed seeds.

\section{Other factors at play}

\section{Allelopathy}

Some cover crop species are considered allelopathic because they produce compounds that are toxic to other plants and organisms (Farooq et al., 2011). Common allelopathic cover crop species include canola (Brassica napus), rapeseed, tillage radish, mustard species (Brassicaceae spp.), cereal rye, wheat (Triticum aestivum), oats (Avena sativa), annual ryegrass (Lolium multiflorum), crimson clover (Trifolium incarnatum), and hairy vetch, (Farooq et al., 2011; Jabran et al., 2015). During growth and when these cover crop species are terminated and incorporated into the soil or left as mulches on the soil surface, the allelopathic compounds leach out and negatively impact germinating seeds (Farooq et al., 2011). Different plants produce different compounds, so mixtures of cover crop species may be more effective at suppressing weeds because they can produce more and a wider variety of allelopathic compounds (Jabran et al., 2015). The allelopathic effects that lead to weed reduction are mostly released as root exudates by the cover crops (Otte et al., 2020). More allelopathic compounds are released shortly after cover crop termination than during growth, potentially because soil microbes can also release allelochemicals themselves, and their abundance increases in response to the additional food source of cover crop residues (Schulz et al., 2013; Otte et al., 2020). Soil allelochemical concentrations from cereal rye were most abundant 3 to 7 days after termination but persisted 56 days before returning to initial concentrations (Otte et al., 2020). A study by Hoffman et al. (1996) found that the radicle length of Bromus secalinus, Vicia villosa, and Setaria viridis was increased due to cereal rye presence in a greenhouse study, attributed to allelopathy and below-ground competition. This same study found that the density of Echinochloa crus-galli leaves was reduced under cereal rye.

Isothiocyanate, a by-product of glucosinolates produced by brassica cover crop species (Jabran et al., 2015), is one of the allelopathic chemicals that suppresses weed seed germination. Didon et al. (2014) used greenhouse and growth chamber studies to test the germination of annual weeds from Scandinavia when cover crop residues were applied. White mustard cover crop residue reduced weed seedling survival $21 \%$ to $57 \%$, and the total biomass of two of the four weeds studied. The same study found that cereal rye and ryegrass only had a moderate allelopathic effect, and a radish cover crop stimulated growth for some weed seeds. However, brassica cover crops had similar effects on reducing (23\% to $34 \%)$ and delaying (2 days) emergence as other common cover crops compared to fallow (Haramoto and Gallandt, 2005).

Allelochemical production can vary based on cultivar and environment (Carlsen et al., 2009), complicating producers' ability to capitalize in allelopathy. Furthermore, weed seed response to allelochemicals can vary based on seed biometry - seeds with high volume and surface area are more sensitive (Pellissier, 2013). Therefore, weeds seeds of this nature are likely the best suppressed with this approach. Future breeding efforts and cultivar screenings are needed to capitalize on the allelopathic potential of cover crops (Carlsen et al., 2009; Schulz et al., 2013).

\section{Habitat provisioning}

Cover crops influence the environment surrounding organisms that influence seed fate, including seed predators, microorganisms, and pathogens. Therefore, if cover crops increase weed seed predation or seed disease, this may be a valuable management tool to 
reduce the seed bank (Sarabi, 2019).

Soil macrofauna, such as earthworms (Lumbricidae), create burrows with their movement and therefore influence oxygen content in the soil (Lee and Foster, 1991). Thus, the presence of cover crops proved to increase earthworm population densities (Roarty et al., 2017). Furthermore, the presence of burrows created by earthworms is known to attract further other micro- and mesofauna (Migge-Kleian et al., 2006).

The presence of other fauna increases the possibility of attracting predators who feed on weed seeds (Carmona and Landis, 1999; White et al., 2007). The overlap between seed availability and seed predator activity needs to be maximized for seed predation (Westerman et al., 2010). For example, a study by Shearin et al. (2008) found that the presence of a pea/oat and cereal rye/hairy vetch cover crop mixture was more than twice as likely to attract the beneficial carabid species such as Harpalus rufipes that may be used as a weed biocontrol option. However, Lewis et al. (2020) did not find an increase in beneficial insects, including predators, in comparing cereal rye, crimson clover, and fallow.

While ground-dwelling invertebrates may be the most important seed predators [accounting for $80 \%$ to $90 \%$ of predated seeds in a study by Cromar et al. (1999)], vertebrates such as rodents are also important, especially along field borders (Sarabi, 2019) but also within fields (Heggenstaller et al. 2016). Furthermore, both vertebrate and invertebrate seed predators prefer denser vegetation, such as from a cover crop (Manson and Stiles, 1998; Shearin et al., 2008; Ward et al., 2011; Heggenstaller et al., 2016). Indeed, cover crops' habitat provisioning increases seed feeding of omnivorous predators (Blubaugh et al. 2016).

Soil microorganisms can cause weed seed decay (Davis et al., 2006). However, only Abutilon theophrasti of eight species evaluated had seed decay linked to microbial activity (Davis, 2007). Similarly, Gallandt et al. (2004) reported that over half of seed bank loss was due to germination and only minor losses were due to seed decay, leading to the conclusion that enhanced microbial decay does not contribute meaningfully to weed management in no-till and conventional till cropping systems. However, other studies found up to $80 \%$ of seed loss due to rotting (Zorner et al., 1984; Gallandt et al., 2006). Differences in results between reports may be explained by the fact that dormancy and resistance-todecay are potentially connected traits (Gallandt et al., 2006). That is, a hard seed coat may keep a seed in dormancy by protecting against microbial attack.

The interaction of pathogens and cover crops has been directly studied. Mohler et al. (2012) report that incorporating green crop residues with tillage increased seedling disease of several common weeds. Potentially, this use of tillage to stimulate germination and increased pathogen activity via green residues could be useful. However, in a seed burial experiment comparing fungicide treated Digitaria sanguinalis seed versus nontreated, differences in decay could not be attributed to fungal pathogens in a cereal rye cover crop (Frost et al., 2019). More research is needed in this area.

\section{Discussion}

We considered each environmental factor affecting dormancy and germination of weed seeds largely independently (Figures 1 and 2), but it is important to note that factors are interrelated and co-dependent. For example, the temperature can influence seed sensitivity to both lights, as observed for Amaranthus tuberculatus and Setaria faberi, where chilling increased light sensitivity (Leon and Owen, 2003) and nitrogen availability (Hilhorst, 1997). Germination of Polygonum aviculare in the dark was much more significant after exposure to moisture fluctuations, but dormancy release was not influenced by moisture level or fluctuations thereof (Batlla et al., 2007). Seeds are most sensitive to light when temperatures indicate a favourable season for the weed (Batlla and Benech-Arnold 2014). Furthermore, changes in light penetration through the cover crop canopy or residue lead to soil temperature and moisture changes. Soil moisture in turn influences oxygen and so forth. Cover crops' impact on these factors changes depending on whether the cover crop is actively growing or is dead residue, which has different implications for seeds that germinate at different times. Furthermore, not all weed species respond to their environment similarly, and successful cover crop performance is not assured. As the complexities of cover crops accumulate, it is difficult to attribute weed seed suppression to individual factors.

While cover crops may maintain dormancy or reduce germination attributable to one or more factors, that may be counteracted by the cover crop's impact on another factor. For example, a cover crop may reduce light availability discouraging germination, but increase soil moisture that encourages germination. Nevertheless, the effects on factors can work together, which should be the focus of management decisions. For example, later termination, which allows for more biomass accumulation, may reduce light, temperature, temperature fluctuations, and nitrogen availability creating a favourable environment for seed predators.

Dormancy may very well be an avoidance mechanism for weeds that would be unsuccessful under cover crop competition. The negative implication is that a more significant number of weed seeds would be left dormant in the soil, waiting for the cover crop to die or decompose. This could potentially lead to greater weed emergence later in the season or subsequent seasons. Dormancy may simply be an avoidance mechanism from a cover crop's ability to suppress weeds, just as dormancy allows weed seeds to avoid other environmental challenges. But maintaining dormancy can also be beneficial as weed seeds are subject to predation, aging, and decay.

Ideally, seeds exit the seed bank by either rotting or predation because these routes do not result in germination and potential crop competition (Zorner et al., 1984). However, the germinable fraction of the seed bank may be of greater importance than the fraction that does not germinate, as this route potentially amounts to over half of annual seed bank losses (Gallandt et al., 2004). Since weed seeds do not compete with the crop, producers must weigh the potential benefits of using cover crops to target the weed seed bank against economic and agronomic realities. Future research should include economic assessments focused on comparing costs for weed management with either the presence or absence of a cover crop, although some exist (Plastina et al., 2020).

\section{Conclusions}

The addition of cover crops to cropping rotations changes the environment surrounding weed seeds and impacts the seed bank in ways that can both promote and inhibit seed survival, dormancy, and germination. The goal of using cover crops for sustainable weed management is to reduce above-ground weed populations, but there is no clear relationship between cover crops and reduced weed seedling density. The multiplicity of cover crop species and mixtures, management options, soil conditions, the differing response between weed species, and environmental conditions 
constrains the researcher's ability to make clear conclusions and complicates management for producers. However, this complexity also makes cover crops a tool that can be adapted to meet different environmental conditions, weed species, and farmer goals.

In general, cover crops that are managed to maximize biomass, do not increase soil nitrogen, and are terminated at or after cash crop planting will have the greatest potential to attenuate the seed bank by decreasing seed survival, maintaining weed seed dormancy, and reducing germination cues. For example, a high biomass cereal rye cover crop will generally maximize light reductions, attenuate soil temperature, decrease soil nitrogen, release allelochemicals, and provide habitat for seed predators. Delaying termination will reduce light germination cues by transitioning the green cover crop canopy to the developing cash crop canopy. This same cover crop may promote weed seedling density through increased soil oxygen and moisture, but these factors are largely beyond the producer's control. Therefore, weed seed bank mitigation should be included as one of the potential benefits that cover crops can provide for farmers. However, it is crucial to understand that every production system is different, and cover crops need to be considered in a case-by-case scenario.

The majority of cover crop and weed research is taking a soilsup perspective, focusing on what is happening with weed suppression at or above the soil surface, instead of thinking about how the soil influences what is germinating - a soil down approach. Few studies look at cover crops and weed seed bank changes specifically, and there are many management factors that make each cover crop system unique. Future research on cover crops and weed management should include measurements of soil seed banks, including dormancy status, predation levels, and germination.

\section{References}

Acharya BS, Dodla S, Gaston LA, Darapuneni M, Wang JJ, Sepat $\mathrm{S}$, and Bohara H, 2019. Winter cover crops effect on soil moisture and soybean growth and yield under different tillage systems. Soil. Till. Res. 195:104430.

Alshallash KS, 2018. Germination of weed species (Avena fatua, Bromus catharticus, Chenopodium album and Phalaris minor) with implications for their dispersal and control. Ann. Agric. Sci. 63:91-7.

Baskin CC, Baskin JM, 1998. Seeds: ecology, biogeography and evolution of dormancy and germination. Academic Press, San Diego, CA, USA.

Batlla D and Benech-Arnold RL, 2014. Weed seed germination and the light environment: Implications for weed management: Light control of weed seed germination. Weed. Bio. Manage. 14:77-87.

Batlla D, Nicoletta M, Benech-Arnold R, 2007. Sensitivity of Polygonum aviculare seeds to light as affected by soil moisture conditions. Ann. Bot. 99:915-24.

Bello I, Hatterman-Valenti H, Owen M, 1998. Effects of stratification, temperature, and oxygen on woolly cupgrass (Eriochloa villosa) seed dormancy. Weed. Sci. 46:526-9.

Benech-Arnold, RL, Sánchez RA, Forcella F, Kruk BC, Ghersa CM, 2000. Environmental control of dormancy in weed seed banks in soil. Food. Crops. Res. 67:105-22.

Benvenuti S, Macchia M, 1995. Effect of hypoxia on buried weed seed germination. Weed. Res. 35:343-51.

Blanco-Canqui H, Mikha MM, Presley DR, Claassen MM, 2011. Addition of cover crops enhances no-till potential for improv- ing soil physical properties. S. Sci. Soc. Am. J. 75:1471-82.

Blubaugh, CK, Hagler, JR, Machtley, SA, Kaplan, I, 2016. Cover crops increase foraging activity of omnivorous predators in seed patches and facilitate weed biological control. Agric. Ecosyst. Environ. 231:264-70.

Boyd N, and Van Acker R, 2004. Seed germination of common weed species as affected by oxygen concentration, light, and osmotic potential. Weed. Sci. 52:589-96.

Carlsen SCK, Kudsk P, Laursen B, Mathiassen SK, Mortensen AG, Fomsgaard IS, 2009. Allelochemicals in rye (Secale cereale L.): Cultivar and tissue differences in the production of benzoxazinoids and phenolic acids. Nat. Prod. Comm. 4:199-208.

Carmona DM, Landis DA, 1999. Influence of refuge habitats and cover crops on seasonal activity-density of ground beetles (Coleoptera: Carabidae) in field crops. Bio. Con. 28:1145-53.

Chen G, Weil RR, Hill RL, 2014. Effects of compaction and cover crops on soil least limiting water range and air permeability. Soil. Till. Res. 136:61-9.

Chen G, Weil RR, 2010. Penetration of cover crop roots through compacted soils. Plant. Soil. 331:31-43.

Clark AJ, Decker AM, Meisinger JJ, and McIntosh MS, 1997. Kill date of vetch, rye, and a vetch-rye mixture: II. Soil moisture and corn yield. Agron. J. 89:434-41.

Cook JC, Gallagher RS, Kaye JP, Lynch J, and Bradley B, 2010. Optimizing vetch nitrogen production and corn nitrogen accumulation under no-till management. Agron. J. 102:1491-9.

Cromar HE, Murphy SD, Swanton CJ. 1999. Influence of tillage and crop residue on post dispersal predation of weed seeds. Weed. Sci. 47:184-94.

Davis, A, 2007. Nitrogen fertilizer and crop residue effects on seed mortality and germination of eight annual weed species. Weed Sci. 55:123-8.

Davis AS, Anderson KI, Hallett SG, Renner KA, 2006. Weed seed mortality in soils with contrasting agricultural management histories. Weed Sci. 54:291-7.

Derkx MPM, Karssen CM, 1994. Are seasonal dormancy patterns in Arabidopsis thaliana regulated by changes in seed sensitivity to light, nitrate and gibberellin? Ann. Bot. 73:129-36.

Didon UM, Kolseth AK, Widmark D, Persson P, 2014. Cover crop residues - Effects on germination and early growth of annual weeds. Weed. Sci. 62:294-302.

Dyer WE, 1995. Exploiting weed seed dormancy and germination requirements through agronomic practices. Weed. Sci. 43:498-503.

Farooq M, Jabran K, Cheema ZA, Wahid A, and Siddique KH, 2011. The role of allelopathy in agricultural pest management. Pest. Manage. Sci. 67:493-506.

Fawcett RS, Slife FW, 1978. Effects of field applications of nitrate on weed seed germination and dormancy. Weed. Sci. 26:594-96.

Forbis TA, Floyd SK, de Queiroz A, 2002. The evolution of embryo size in angiosperms and other seed plants: Implications for the evolution of seed dormancy. Evo. 56:2112-25.

Frost MD, Haramoto ER, Renner KA, Brainard DC, 2019. Tillage and cover crop effects on weed seed persistence: Do light exposure and fungal pathogens play a role?. Weed. Sci. 67:103-13.

Gallagher RS, Cardina J, 1998. Phytochrome-mediated Amaranthus germination I: effect of seed burial and germination temperature. Weed. Sci. 46:48-52.

Gallandt ER, 2006. How can we target the weed seedbank? Weed. Sci. 54:588-96.

Gallandt ER, Fuerst EP, Kennedy AC, 2004. Effect of tillage, fungicide seed treatment, and soil fumigation on seed bank 
dynamics of wild oat (Avena fatua). Weed. Sci. 52:597-604.

Geneve R, 2003. Impact of temperature on seed dormancy. Hort. Sci. 38:336-41.

Haramoto, E, Gallandt, E, 2005. Brassica cover cropping: I. Effects on weed and crop establishment. Weed Sci. 53:695-701.

Haring SC, Flessner ML, 2018. Improving soil seed bank management. Pest. Manage. Sci. 74:2412-8.

Heggenstaller AH, Menalled FD, Liebman M, Westerman PR, 2006. Seasonal patterns in post-dispersal seed predation of Abutilon theophrasti and Setaria faberi in three cropping systems. J Appl. Ecol. 43:999-1010.

Hilhorst HWM, Toorop PE, 1997. Review on dormancy, germinability, and germination in crop and weed seeds. Adv. Agr. Els. 61:111-65.

Hoffman ML, Regnier EE, Cardina J, 1993. Weed and corn (Zea mays) responses to a hairy vetch (Vicia villosa) cover crop. Weed. Tech. 7:594-9.

Hoffman ML, Weston LA, Snyder JC, Regnier EE, 1996. Allelopathic influence of germinating seeds and seedlings of cover crops on weed species. Weed. Sci. 44:579-84.

Horn R, Taubner H, Wuttke M, Baumgartl T, 1994. Soil physical properties related to soil structure. Soil. Till. Res. 30:187-216.

Jabran K, Mahajan G, Sardana V, Chauhan BS, 2015. Allelopathy for weed control in agricultural systems. Crop. Prot. 72:57-65.

Jha P, Norsworth JK, Riley MB, Bridges Jr. W, 2010. Annual changes in temperature and light requirements for germination of Palmer amaranth (Amaranthus palmeri) seeds retrieved from soil. Weed. Sci. 58:426-32.

Jian J, Du X, Reiter MS, Stewart RD, 2020. A meta-analysis of global cropland soil carbon changes due to cover cropping. Soil. Bio. Bio. 143:107735.

Joyce BA, Wallender WW, Mitchell JP, Huyck LM, Temple SR, Brostrom PN, Hsiao TC, 2002. Infiltration and soil water storage under winter cover cropping in California's Sacramento Valley. Trans. ASAE. 45:315.

Kahimba FC, Ranjan RS, Froese J, Entz M, Nason R, 2008. Cover crop effects on infiltration, soil temperature, and soil moisture distribution in the Canadian Prairies. App. Eng. Ag. 24:321-33.

Kaye J, Finney D, White C, Bradley B, Schipanski M, AlonsoAyuso M, Hunter M, Burgess M, Mejia C, 2019. Managing nitrogen through cover crop species selection in the U.S. midAtlantic. Pls. On. 14:e0215448.

Lee KE, Foster RC, 1991. Soil fauna and soil structure. Sci. Res. 29:745-75.

Lemon ER, Erickson AE, 1952. The measurement of oxygen diffusion in the soil with a platinum microelectrode. Soil. Sci. Soc. Am. J. 16:160-3.

Leon RG, Owen MDK, 2003. Regulation of weed seed dormancy through light and temperature interactions. Weed. Sci. 51:752-8.

Liebl R, Summons WF, Wax LM, Stoller EW, 1992. Effect of rye (Secale cereale) mulch on weed control and soil moisture in soybean (Glycine max). Weed. Tech. 6:838-46.

Manson R, Stiles EW, 1998. Links between microhabitat preferences and seed predation by small mammals in old fields. Oikos 82:37-50

Migge-Kleian S, McLean MA, Maerz JC, Heneghan L, 2006. The influence of invasive earthworms on indigenous fauna in ecosystems previously uninhabited by earthworms. Bio. Inv. $8: 1275-85$.

Mirsky SB, Gallandt ER, Mortensen DA, Curran WS, Shumway DL, 2010. Reducing the germinable weed seedbank with soil disturbance and cover crops. Weed. Res. 50:341-52.

Mirsky SB, Ryan MR, Teasdale JR, Curran WS, Reberg-Horton
CS, Spargo JT, Wells MS, Keene CL, Moyer JW, 2013. Overcoming weed management challenges in cover cropbased organic rotational no-till soybean production in the Eastern United States. Weed. Tech. 27:193-203.

Mohler CL, Dykeman C, Nelson EB, Ditommaso A, 2012. Reduction in weed seedling emergence by pathogens following the incorporation of green crop residue. Weed. Res. 52:467-77.

Mohler CL, Taylor AG, DiTommaso A, Hahn RR, Bellinder RR, 2018. Effects of incorporated rye and hairy vetch cover crop residue on the persistence of weed seeds in the soil. Weed. Sci. $66: 379-85$

Osipitan OA, Dille JA, Assefa Y, Knezevic SZ, 2018. Cover crop for early season weed suppression in crops: Systematic review and meta-analysis. Agron. J. 110:2211-21.

Otte BA, Rice CP, Davis BW, Schomberg HH, Mirsky SB, Tully KL, 2020. Phenolic acids released to soil during cereal rye cover crop decomposition. Chemeco. 30:25-34.

Pickett ST, Baskin JM, 1973. The role of temperature and light in the germination behavior of Ambrosia artemisiifolia. Bull. Tor. Bot. Clb. 100:165-70.

Plastina A, Liu F, Miguez F, Carlson S, 2020. Cover crops use in Midwestern US agriculture: perceived benefits and net returns. Renew. Ag. Food Syst. 35:38-48.

Powles SB, Gaines TA, 2018 Exploring the potential for a regulatory change to encourage diversity in herbicide use. Weed. Sci. 64:649-54

Rector L, 2019. Herbicide carryover to cover crops and evaluation of cover crops for annual weed control in corn and soybeans. Degree thesis. Virginia Tech, Blacksburg, Virginia, USA.

Roarty S, Hackett RA, Schmidt O, 2017. Earthworm populations in twelve cover crop and weed management combinations. App. Soil. Eco. 114:142-51.

Rius M, Darling JA, 2014. How important is intraspecific genetic admixture to the success of colonising populations? Trends Ecol Evol 29:233-42

Sainju UM, Singh BP, Whitehead WF, 1998. Cover crop root distribution and its effects on soil nitrogen cycling. Agro. J. 90:511-8

Sarabi V, 2019. Factors that influence the level of weed seed predation: A review. Weed. Bio. Manage. 19:61-74.

Schimpf DJ, Palmblad IG, 1980. Germination response of weed seeds to soil nitrate and ammonium with and without simulated overwintering. Weed. Sci. 28:190-3.

Schulz M, Marocco A, Tabaglio V, Tabaglio V, Macias FA, Molinillo JMG, 2013. Benzoxazinoids in rye allelopathy From discovery to application in sustainable weed control and organic farming. J. Chem. Ecol. 39:154-74.

Sexsmith JJ, Pittman UJ, 1963. Effect of nitrogen fertilizers on germination and stand of wild oats. Weeds. 11:99-101.

Shearin AF, Reberg-Horton SC, Gallandt ER, 2008. Cover crop effects on the activity-density of the weed seed predator Harpalus rufipes (Coleoptera: Carabidae). Weed. Sci. 56:442-50.

Sievers T, Cook RL, 2018. Aboveground and root decomposition of cereal rye and hairy vetch cover crops. Soil. Sci. Soc. Am. J. 82:147-55.

Stewart RD, Jian J, Gyawali AJ, Thomason WE, Badgley BD, Reiter MS, Strickland MS, 2018. What we talk about when we talk about soil health. Agric. Env. Lett. 3:180033.

Teasdale JR, 1996. Contribution of cover crops to weed management in sustainable agricultural systems. J. Prod. Agric. 9:475-9.

Teasdale JR, Daughtry CST, 1993. Weed suppression by live and desiccated hairy vetch (Vicia villosa). Weed. Sci. 41:207-12. 
Teasdale JR, Mohler CL, 1993. Light transmittance, soil temperature, and soil moisture under residue of hairy vetch and rye. Agron. J. 85:673-80.

Thompson K, Grime JP, 1983. A comparative study of germination responses to diurnally-fluctuating temperatures. J. Apld. Eco. 20:141-56.

Villamil MB, Bollero GA, Darmody RG, Simmons FW, Bullock DG, 2006. No-till corn/soybean systems including winter cover crops. Soil. Sci. Soc. Am. J. 70:1936-44.

Ward MJ, Ryan MR, Curran WS, Barbercheck ME, Mortensen DA, 2011. Cover crops and disturbance influence activity-density of weed seed predators Amara aenea and Harpalus pensylvanicus (Coleoptera: Carabidae). Weed. Sci. 59:76-81.

Wayman S, Cogger C, Benedict C, Collins D, Burke I, Bary A,
2015. Cover crop effects on light, nitrogen, and weeds in organic reduced tillage. Agroeco. Sust. Food. Syst. 39:647-65.

Weil R, Kremen A, 2007. Thinking across and beyond disciplines to make cover crops pay. J. Sci. Food. Agric. 87:551-57.

White SS, Renner KA, Menalled FD, Landis DA, 2007. Feeding preferences of weed seed predators and effect on weed emergence. Weeds. 55:606-12.

Zhu JC, Gantzer CJ, Anderson SH, Alberts EE, Beuselinck PR, 1989. Runoff, soil, and dissolved nutrient losses from no-till soybean with winter cover crops. Soil. Sci. Soc. Am. J. 53:1210-4.

Zorner PS, Zimdahl RL, Schweizer EE, 1984. Sources of viable seed loss in buried dormant and non-dormant populations of wild oat (Avena fatua L.) seed in Colorado. Wd. Res. 24:143-50. 